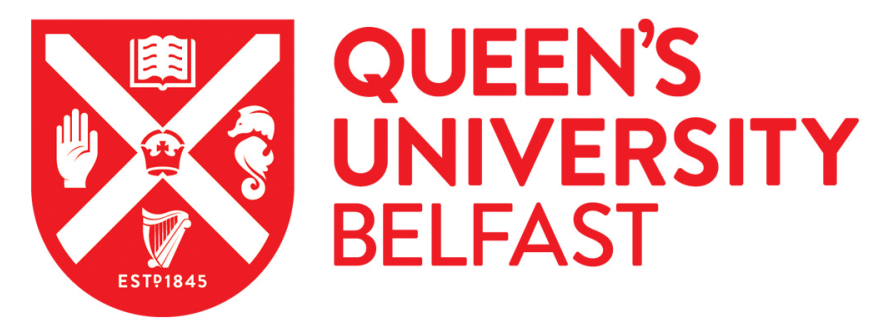

\title{
Testing the cause of the Sphagnum austinii (Sull. ex Aust.) decline: Multiproxy evidence from a raised bog in Northern Ireland
}

\author{
Swindles, G. T., Turner, T. E., Roe, H. M., Hall, V. A., \& Rea, H. A. (2015). Testing the cause of the Sphagnum \\ austinii (Sull. ex Aust.) decline: Multiproxy evidence from a raised bog in Northern Ireland. Review of \\ Palaeobotany and Palynology, 213, 17-26. https://doi.org/10.1016/j.revpalbo.2014.11.001
}

Published in:

Review of Palaeobotany and Palynology

Document Version:

Peer reviewed version

Queen's University Belfast - Research Portal:

Link to publication record in Queen's University Belfast Research Portal

\begin{abstract}
Publisher rights
Copyright ( 2014 Elsevier B.V. All rights reserved.

This is the author's version of a work that was accepted for publication in Review of Palaeobotany and Palynology. Changes resulting from the publishing process, such as peer review, editing, corrections, structural formatting, and other quality control mechanisms may not be reflected in this document. Changes may have been made to this work since it was submitted for publication. A definitive version was subsequently published in Review of Palaeobotany and Palynology, vol. 213, February 2015, doi:10.1016/j.revpalbo.2014.11.001.

\section{General rights}

Copyright for the publications made accessible via the Queen's University Belfast Research Portal is retained by the author(s) and / or other copyright owners and it is a condition of accessing these publications that users recognise and abide by the legal requirements associated with these rights.
\end{abstract}

Take down policy

The Research Portal is Queen's institutional repository that provides access to Queen's research output. Every effort has been made to ensure that content in the Research Portal does not infringe any person's rights, or applicable UK laws. If you discover content in the Research Portal that you believe breaches copyright or violates any law, please contact openaccess@qub.ac.uk. 


\section{Accepted Manuscript}

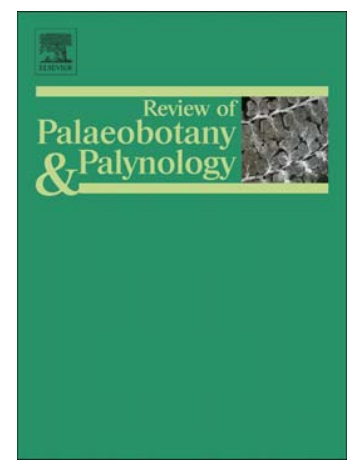

Testing the cause of the Sphagnum austinii (Sull. ex Aust.) decline: Multiproxy evidence from a raised bog in Northern Ireland

Graeme T. Swindles, T. Edward Turner, Helen M. Roe, Valerie A. Hall, Heidi A. Rea

PII: $\quad$ S0034-6667(14)00160-2

DOI: $\quad$ doi: $10.1016 /$ j.revpalbo.2014.11.001

Reference: $\quad$ PALBO 3580

To appear in: $\quad$ Review of Palaeobotany and Palynology

Received date: 12 September 2013

Revised date: $\quad 25$ July 2014

Accepted date: $\quad 5$ November 2014

Please cite this article as: Swindles, Graeme T., Turner, T. Edward, Roe, Helen M., Hall, Valerie A., Rea, Heidi A., Testing the cause of the Sphagnum austinii (Sull. ex Aust.) decline: Multiproxy evidence from a raised bog in Northern Ireland, Review of Palaeobotany and Palynology (2014), doi: 10.1016/j.revpalbo.2014.11.001

This is a PDF file of an unedited manuscript that has been accepted for publication. As a service to our customers we are providing this early version of the manuscript. The manuscript will undergo copyediting, typesetting, and review of the resulting proof before it is published in its final form. Please note that during the production process errors may be discovered which could affect the content, and all legal disclaimers that apply to the journal pertain. 


\section{Testing the cause of the Sphagnum austinii (Sull. ex Aust.) decline:}

\section{multiproxy evidence from a raised bog in Northern Ireland}

Graeme T. Swindles ${ }^{1^{*}}$, T. Edward Turner ${ }^{1}$, Helen M. Roe ${ }^{2}$, Valerie A. Hall ${ }^{2}$, Heidi A. Rea ${ }^{2}$

${ }^{1}$ School of Geography, University of Leeds, Leeds, LS2 9JT, UK

${ }^{2}$ School of Geography, Archaeology and Palaeoecology, Queen's University Belfast, Belfast, BT7 1NN,

UK

Manuscript for Review of Palaeobotany and Palynology

*Corresponding author

g.t.swindles@leeds.ac.uk

+44 (0)11334 39127

\section{Keywords}

Sphagnum austinii; Sphagnum imbricatum; land-use; late Holocene; raised bog; Ireland 


\section{Abstract}

We use a multiproxy palaeoecological dataset from Dead Island bog in Northern Ireland to examine the cause of the Sphagnum austinii (Sphagnum imbricatum) decline. The disappearance of this species from the peat record occurred just after the 'AD 860 ' tephra layer and is coeval with a rapid increase in bog surface wetness and increased mineral dust and charcoal abundance. Although it is difficult to identify one specific cause of the decline, the evidence for increased soil-derived dust is apparent and is supported by regional tephra-dated pollen diagrams that reveal extensive landscape changes due to agricultural intensification in early Medieval Ireland. As the decline of Sphagnum austinii occurred much later ( $\sim A D$ 1860) in Fallahogy bog ( 1.2 km away), we suggest that the decline of Sphagnum austinii at Dead Island was caused by a combination of fire and the deposition of soil-derived dust. We suggest that future studies should consider the use of multiple cores from each site to examine the within-site variability of the decline of Sphagnum austinii. 


\section{Introduction}

The use of plant macrofossils for investigating ecological change in peatland vegetation and to infer past hydrological conditions is well-established (Barber et al., 1994; Barber et al., 1998; Hughes et al., 2000; Swindles et al., 2007; Mauquoy et al., 2008). The relationship between plant macrofossils and surface wetness is reasonably well understood from the analysis of modern vegetation communities (e.g. Väliranta et al., 2012) and thus hydrological interpretation from plant macrofossil assemblages in peats is firmly based on uniformitarianism (Stoneman et al., 1993). However, a common problem species for peatland palaeoecological research is Sphagnum austinii Sull. ex Aust. (formerly S. imbricatum Hornsch. Ex Russ.). This moss has been established as an ombrotrophic bog taxon, separate from the fen taxon Sphagnum affine (Thingsgaard, 2002), and recognized as a distinct species in the revised bryophyte flora of the British Isles (Smith, 2004).

In the past, S. austinii was abundant in many peatlands across the United Kingdom, Ireland and North West Europe, but in the British Isles is now generally confined to only a few sites in Scotland, NW Wales and Ireland. Where this species is still present it is often forms large, dense hummocks (Daniels and Eddy, 1990). The decline of Sphagnum austinii is said to represent "the most striking vegetation change on the raised bogs of Britain and Northwest Europe during the last 2000 years" (Hughes et al., 2008: p.1033); however, its contraction of range shows no uniformity either temporally or spatially.

The scarcity of Sphagnum austinii in modern peatland vegetation communities causes difficulties when developing quantitative palaeohydrological inferences from fossil plant macrofossil assemblages. This species once formed a great bulk of Holocene peat, but the precise conditions under which it prospered in the past remain an enigma (Green, 1968). At some sites the decline of S. austinii occurred over only a few decades, and the main phase of decline is generally between cal. AD 1030-1730 (McClymont et al., 2008). S. austinii is often replaced in peat stratigraphy by other 
Sphagna including S. magellanicum, S. sect. Cuspidata, S. papillosum or S. sect. Acutifolia (van Geel and Middeldorp, 1988; Mauquoy and Barber, 1999). The driving forces behind the decline remain unqualified and greatly disputed with a number of hypotheses put forward, such as:

(i) Increased bog surface wetness (BSW) and climate change. At some sites the decline of S. austinii is associated with increased mire surface wetness (McClymont et al., 2008; Mauquoy and Barber, 1999). Palaeoecological data from Butterburn Flow in Northern England suggest that a combination of increased BSW and changing aeolian nutrient inputs (see iii) caused the disappearance of $S$. austinii (McClymont et al., 2008). However, evidence from Cars Caron bog in Wales shows that this species has survived similar shifts in BSW in the past, where it declined to trace levels and then regained dominance when the wet phase ended (Hughes et al., 2007). It has been suggested that climate may have driven the increased mire surface wetness leading to the decline of S. austinii (e.g. Mauquoy and Barber, 1999). However, the role of climate change in the loss of S. austinii has been disputed, since the species has survived well-documented past climatic events. For example, in Raheenmore in Ireland, the species is still present alongside S. magellanicum, having re-established itself after the 'Little Ice Age' (LIA) (Schulz, 2004). Given earlier discussions on the low genetic diversity of S. austinii, it is likely all colonies would react in a similar manner to any broad scale shifts to climate, but this is shown to not be the case (Hughes et al., 2007).

(ii) Competition. Other research has suggested interaction and growth competition between species were a driving force in the disappearance of this taxon (Flatberg, 1986). For example, at two sites in Northern England, inter-specific competition, coinciding with shifts in climate have been proposed as the reason for the loss (Mauquoy and Barber, 1999). Conversely, Gunnarson (2005) has suggested that S. austinii and S. magellanicum are competitively equal as they have the same annual production rates. This would imply inter-specific competition in relation to changing BSW is 
negligible (Robroek et al., 2007; 2009). There are differences in the attributes of different Sphagnum species (e.g. physiology, limiting factors and tolerances) that lead to variations in their relative resilience to changing environmental factors such as nutrient deposition and hydrological change (Hill et al., 2007). However, there is no evidence in moss attribute data (e.g. Ellenberg indicator values - Ellenberg et al., 1991; Hill et al., 1999) to suggest that other common peatland Sphagna (e.g Sphagnum capillifolium, Sphagnum papillosum and Sphagnum magellanicum) have a wider tolerance to environmental factors (light, moisture, $\mathrm{pH}$, Nitrogen, salt tolerance, heavy metal tolerance) than S. austinii.

(iii) Changes in nutrient and other atmospheric inputs. With many Sphagnum species being extremely sensitive to solute supply (e.g. Lee et al., 1993), changes in nutrients and atmospheric inputs have been suggested as a driving factor in the loss of S. austinii. At Carbury Bog in Ireland, an increase in nitrogen levels was proposed as the cause behind the replacement of $S$. austinii by $S$. magellanicum (van Geel and Middeldorp, 1988). This was linked to agricultural intensification in the area surrounding the bog, marked by a decrease in tree pollen, and an increase in atmospheric dust levels. However, the presence of $S$. austinii in a number of Irish bogs where present day atmospheric $\mathrm{N}$ deposition is likely to be greater complicates this argument (Robroek et al., 2009). Other studies have discussed major changes in peatland ecosystems driven by inputs of atmospheric dust and tephra (e.g. Ireland and Booth, 2012; Hughes et al., 2013).

(iv) Direct human disturbance on sites. Anthropogenic impact on sites, through burning and drainage, has also been suggested to be one possible reason for the decline of this "sensitive" species (Hill, 1988). Eriophorum vaginatum has been shown to temporarily dominate peatland vegetation communities following burning events (Bragg and Tallis, 2001, Holden et al., 2007). Roebroek et al. (2009) suggest that this results in a fluctuating water table, which allows species that 
thrive in a wide range of hydrological conditions to rapidly colonise post burning. e.g. S. magellanicum. Over the last 2000 years, land-use intensity has increased in areas surrounding peatlands and this is suggested to be linked to the decline of S. austinii. In Cors Caron (Wales), and Abbeyknockmoy bog (Ireland), land use changes identified from pollen records provide evidence for the re-establishment of the species in phases of reduced human activity (Hughes et al., 2007; Hughes et al., 2008).

(v) Genetic erosion. Sphagnum austinii has been established as a "genetically eroded" (Thingsgaard, 2002: pg. 3) species due to postglacial migration, causing severe genetic bottlenecks caused by a series of founder effects. This loss of genetic diversity has left this species requiring specific conditions of low productivity (in which few other moss species will survive) as well as an oceanic climate providing constant humidity for it to thrive (Thingsgaard, 2002); conditions which few sites now meet.

(vi) Taxonomic error. It has even been theorized that the identification of S. austinii in peatland hollow microforms prior to its decline may reflect a misidentification of $S$. affine, due to its coexistence with S. section Cuspidata (Thingsgaard, 2002). However, it is generally accepted that any such taxonomic issues cannot account for the decline of this species.

In this paper we attempt to test the cause of the decline of Sphagnum austinii in a raised bog in Northern Ireland, using a multiproxy palaeoecological approach. We test the hypothesis that the aerial deposition of soil dust caused the decline of Sphagnum austinii as proposed by Hughes et al., (2008).

\section{Study site}


Dead Island is a lowland raised bog lying in a shallow inter-drumlin hollow within the Lower Bann valley (Fig. 1). The site has a large intact core of deep peat (Fig. 2) with shallow pools and a welldeveloped hummock and lawn complex. The surface vegetation at Dead Island comprises Calluna vulgaris, Erica tetralix, Eriophorum vaginatum, Eriophorum angustifolium, Scirpus cespitosus, Sphagnum capillifolium and a few isolated hummocks of Sphagnum austinii.

Bog pools are dominated by Sphagnum cuspidatum and are often fringed by Sphagnum magellanicum, Sphagnum papillosum and in some places Sphagnum tenellum. Vaccinium oxycoccos is also present in a number of wetter locations. Other plants include Rhynchospora alba, Narthecium ossifragum, Drosera rotundifolia and Cladonia lichens. Mean January and July temperatures at the site are $4-6$ and $12-16^{\circ} \mathrm{C}$ respectively. Mean annual rainfall is between $900-1000 \mathrm{~mm}$ and mean annual potential evapotranspiration is between $400-450 \mathrm{~mm}$ (Swindles, 2006).

\section{Methods}

A core was extracted from a lawn microform on the main bog cupola at Dead Island using a widecapacity Russian D-section corer with a $50 \mathrm{~cm}$ long chamber (Jowsey, 1966; De Vleeschouwer et al., 2010). The cores were wrapped in aluminium foil, returned to the laboratory and stored in refrigeration at $4{ }^{\circ} \mathrm{C}$. The core was generally composed of Sphagnum peat with some Calluna and Eriophorum and occasional pool-mud horizons. Testate amoebae were extracted from the samples using a modified version of the method described by Hendon and Charman (1997) as deionised water was used as a storage medium and mountant rather than glycerol. Testate amoebae were identified using Charman et al. (2000). Peatland water table reconstructions were carried out using the ACCROTELM pan-European and North of Ireland transfer functions (Charman et al., 2007; Swindles et al., 2009). Humification and plant macrofossil analyses were undertaken following RoosBarraclough (2004) and Barber et al. (1994). Plant macrofossils were identified using Grosse- 
Brauckmann (1972, 1974, 1992) and Katz et al. (1977). Loss-on-ignition analysis was carried out following Schulte and Hopkins (1996) to evaluate aeolian inputs to the peatland. The resulting ashes from loss-on-ignition were washed in a $10 \mu \mathrm{m}$ mesh and mounted on slides using Histomount. The abundance of quartz grains were estimated on an ordinal 0-5 scale (where 0 signifies absence and 5 is very abundant). Macro-charcoal particles were also counted in the plant macrofossil samples and evaluated on the same scale. The Dead Island core chronology is based on tephrochronology, AMS

${ }^{14} \mathrm{C}$ dating and spheroidal carbonaceous particles as fully described in Swindles et al. (2010a, 2012). The cryptotephras were extracted following Swindles et al. (2010b) and analysed by electron microprobe microanalysis at Edinburgh and Leeds Universities (Fig. 3).

\section{Results and discussion}

The decline of Sphagnum austinii at Dead Island occurred just after the AD 860 tephra layer and before the Hekla 1104 tephra layer (Figs 4 and 5), and is thus dated to c. AD 980. It is replaced by Sphagnum magellanicum and Sphagnum papillosum. The decline occurred at a time of increased bog surface wetness, reduced loss-on-ignition values,increased quartz abundance as well as a peak in macro-charcoal. Tephra-linked pollen data from nearby sites in the Lower Bann Valley are shown in Fig. 1 and show a phase of major human impact on the landscape centred on the AD 860 tephra. This phase is characterised by a decrease in arboreal pollen percentages (Alnus, Betula, Corylus-type and Quercus) suggesting scrub and woodland clearance in the Lower Bann Valley (Fig. 6). An increase in grasses (Poaceae), sedges (Cyperaceae) and agricultural taxa (Cerealia-type, Secale-type) is observed. The presence of Secale-type (rye) and Linum (flax) pollen may suggest increasing arable activity close to this site (Hall et al., 1993). This implies that the increased aeolian soil dust in Dead Island at this time (causing the increased quartz and lower loss-on-ignition results) was due to widespread landscape clearance and agricultural intensification across the Bann Valley. The topographic setting of Dead Island may have accentuated the aeolian inputs as the drumlins 
surrounding the site would have offered better-drained land suitable for cultivation. A slower peat accumulation rate in the last millennium at Dead Island has been noted (e.g. Swindles et al., 2012). However, the decline of $S$. austinii and the coeval rise of quartz occurred before the onset of this slowdown of peat accumulation (Supplementary material 2). The changes in the pollen data at the same time (Fig. 6) suggest that the increase in quartz is the product of soil erosion by wind resulting from landscape clearance in the Lower Bann Valley rather than due to any changes in peataccumulation dynamics. A sample of the dust from the peat at the horizon containing the S. austinii decline was extracted and subjected to x-ray diffraction (XRD) analysis alongside nine soil samples from around Dead Island (Swindles, 2006). The XRD analysis shows that the dust does not contain any minerals that would indicate anything other than a local provenance (Swindles, 2006; Supplementary material 3).

The abundance of Sphagnum austinii in the complete sequence is correlated (using Spearman's rank) with quartz abundance $\left(r_{s}=-0.471, p<0.01\right)$, charcoal $\left(r_{s}=-0.363, p<0.01\right)$ and loss-on-ignition $\left(r_{s}=0.288, p<0.05\right)$ (Table 1). There is no significant relationship between the abundance of Sphagnum austinii and the testate amoeba-derived water table reconstructions. Non-metric multidimensional scaling (NMDS) and redundancy analysis (RDA) show that S. austinii plots where loss-on-ignition is high and quartz and charcoal abundance is low, suggesting that these are important factors in determining the success of this species (Fig. 7).

The disappearance of Sphagnum austinii is a major feature of peat stratigraphy across the British Isles (e.g. Mauquoy and Barber, 1999; Hughes et al., 2008) that generally occurred within the past 2,000 years, although dates of the decline are highly variable (Hughes et al., 2000; Barber et al., 2003; Langdon and Barber, 2005; Fig. 7, Table 2). The decline has been linked in previous studies to aerial deposition of soil dust in Cors Caron, Wales and Carbury and Abbeyknockmoy bogs, Ireland (van Geel and Middeldorp, 1988; Hughes et al., 2008). Furthermore, at a site in northern England, 
Malham Tarn Moss, the very early disappearance of S. austinii at c. AD 26 coincides with increased $\mathrm{Ti}, \mathrm{Y}$ and $\mathrm{Rb}$ suggesting soil dust loading of the bog surface (Turner et al., 2014) The pollen record at this site indicates a reduction in arboreal taxa, replaced by increasing proportions of Cyperaceae, Poaceae and Plantago sp. pollen. The deposition of soil-derived dust on a peatland surface may be detrimental to Sphagnum austinii (e.g. Farmer, 1993) or the deposition of N may benefit competitors including other Sphagna (Lee et al., 1993).

The United Nation Economic Commission for Europe state a critical N load of 5-10 kg N ha ${ }^{-1} \mathrm{y}^{-1}$ for raised and blanket bogs (APIS, 2012), leading Hughes et al., (2008) to suggest a critical N deposition threshold of $<10 \mathrm{~kg} \mathrm{~N} \mathrm{ha}^{-1} \mathrm{y}^{-1}$ for the current day presence of Sphagnum austinii in raised bogs across the British Isles. However, the average total $\mathbf{N}$ deposition at Dead Island bog in the recent past (2004-2011) was $11.31 \mathrm{~kg} \mathrm{~N} \mathrm{ha}^{-1} \mathrm{y}^{-1}$, with a maximum of $13.84 \mathrm{~kg} \mathrm{~N} \mathrm{ha}^{-1} \mathrm{y}^{-1}$ in 2011 (Defra). This would suggest that $S$. austinii may be able to tolerate higher concentrations of $\mathrm{N}$ that previously stated. It could be argued that the ecological effects of $\mathrm{N}$ loading are yet to be realised; however, atmospheric $\mathrm{N}$ deposition has been in decline over the last three decades (Fowler et al., 2005) thus it can be concluded that this is unlikely. Clearly, the past and current presence of S. austinii at Dead Island have been driven by other factors. It is possible that the combination of burning (as there is an increase in charcoal at the time of the decline) and deposition of soil dust caused the decline of $S$. austinii at Dead Island. In Fallahogy raised bog, which is $\sim 1.2 \mathrm{~km}$ to the north of Dead Island, there is a subfossil presence of $S$. austinii until AD1860 (Rea, 2011). This much later date of the decline suggests that site-specific factors, such as burning, must have been important.

A recent study found that there is significant within-site variability of subfossil pollen and macrofossil records in a peatland in the Netherlands (Blaauw and Mauquoy, 2012). The presence of Sphagnum austinii in hummocks on the present surface of both Dead Island and Fallahogy suggests that the 
decline of Sphagnum austinii was temporally variable in each peatland. Within-site variability as well as between-site variability may explain the wide variety of dates obtained for the decline of Sphagnum austinii in the British Isles (Table 2, Fig. 8). Thus, future studies should consider analysis of several peat cores from each site to investigate the within-site variability.

The cause of the decline of Sphagnum austinii may never be fully understood, but the importance of this event in peat-based palaeoenvironmental studies will lead to research into this topic for many years to come. The use and study of contemporary and subfossil plant DNA may have important implications for linking the modern and fossil specimens of this species and understanding its palaeoecology and phylogeography (e.g. Szövényi et al., 2006; Suyama et al., 2008). This may offer further insights into why Sphagnum austinii suffered such a dramatic loss in the peatlands of Britain and Ireland.

\section{Conclusions}

1. A multiproxy palaeoecological dataset from Dead Island raised bog, Northern Ireland is used to examine the cause of the decline of Sphagnum austinii (Sphagnum imbricatum).

2. The decline of Sphagnum austinii in Dead Island bog occurred just after the 'AD 860' tephra layer and is coincident with a water table rise, increased mineral dust and charcoal.

3. Significant correlations are found between the abundance of Sphagnum austinii and charcoal, loss on ignition and quartz abundance. There is no significant correlations between the abundance of Sphagnum austinii and a testate amoebae-based water table reconstruction.

4. Although it is difficult to identity one clear cause of the decline, the results suggest that increased soil-derived dust may have been an important factor, corroborating results from elsewhere in the British Isles. However, the diachronous nature of the decline in two 
proximal sites suggest that site-specific factors may be important. The increase in charcoal at Dead Island may suggest that fire was an important factor.

5. Future studies should consider within-site as well as between-site variability in the timing and nature of the decline of Sphagnum austinii.

\section{Acknowledgements}

We thank the Natural Environment Research Council for funding tephra geochemical analysis. This research was carried out during a doctoral degree funded by DEL-NI (GTS).

\section{Figure captions}

Figure 1. Aerial photo of Dead Island bog (RAF, 1955) and map showing the location of study sites. The location of the core analysed here is shown on the aerial photo.

Figure 2. Stratigraphy of Dead Island bog (N-S transect).

Figure 3. Ternary diagram of tephra geochemistry from Dead Island (major element oxides as determined by EPMA). Geochemical data is provided in Swindles et al. (2010a).

Figure 4. Multiproxy palaeoenvironmental dataset from Dead Island for the top $1 \mathrm{~m}$ (plant macrofossils, testate amoebae and peat properties. Water table reconstructions are based on the Northern Ireland (Swindles et al., 2008) and European (Charman et al., 2007) transfer functions. The positions of the tephra layers are shown. Charcoal and quartz grains are expressed on a relative abundance scale. The prehistoric tephras have been dated to 755-680 cal. BC for $\mathrm{OMH}-185,800-758$ cal. BC for GB4-150 and 2395-2279 cal. BC for Hekla 4 (Pilcher et al., 1995; Plunkett et al., 2004). 
Figure 5. Multiproxy palaeoenvironmental dataset from Dead Island for the complete sequence (plant macrofossils, testate amoebae and peat properties). Water table reconstructions are based on the Northern Ireland (Swindles et al., 2009) and European (Charman et al., 2007) transfer functions. The positions of the tephra layers are shown. Charcoal and quartz grains are expressed on a relative abundance scale. The prehistoric tephras have been dated to $755-680 \mathrm{cal}$. BC for $\mathrm{OMH}-185,800-758$ cal. BC for GB4-150 and 2395-2279 cal. BC for Hekla 4 (Pilcher et al., 1995; Plunkett et al., 2004).

Figure 6. Tephra linked pollen diagrams from the Bann Valley: (a) Fallahogy; (b) Ballyscullion East (after Hall et al., 1993, data is from the Global Pollen Database http://www.ncdc.noaa.gov/paleo/pollen.html). The AD860 and Hekla 1104 tephra layers are shown (grey screens). The phases of decreased arboreal pollen reflecting widespread landscape clearances are highlighted by pink boxes.

Figure 7. NMDS and RDA analysis of the plant macrofossil data. Peat properties and water table reconstructions were included as environmental variables in the RDA. The Bray-Curtis distance was used in NMDS and the samples were classified based on the ordinal scores of quartz (1-5; see data in Figures 4 and 5). Taxon data were Hellinger-transformed prior to RDA analysis. Sphagnum austinii is abbreviated as 'SA' (full names for the other taxa can be found in Figures 4 and 5).

Figure 8. Histogram showing the dates of the decline of Sphagnum austinii in Britain and Ireland. The red line is a kernel density function, the black line is the normal distribution.

Table 1. Spearman's correlation coefficients showing the relationships between \% Sphagnum austinii and other down-core variables. 
Table 2. Comparison of the dates of decline of Sphagnum austinii in peatlands of Britain and Ireland.

Supplementary file 1. Attributes of common peatland Sphagna from Bryoatt tables (Hill et al., 2007).

Supplementary file 2. Bacon age-depth model for Dead Island (for full details see Swindles et al. (2014).

Supplementary file 3. $x$-ray diffractogram for a Dead Island peat sample $(38-43 \mathrm{~cm})$ and nine local soils.

\section{References}

APIS, 2012. Summary of Nutrient Nitrogen Critical Loads from Noordwijkerhout Workshop June 2010, UN Economic and Social Council.

http://www.apis.ac.uk/overview/issues/overview_Noordwijkerhout_text.html

Barber, K., Dumayne-Peaty, L., Hughes, P., Mauquoy, D., Scaife, R., 1998. Replicability and variability of the recent macrofossil and proxy-climate record from raised bogs: field stratigraphy and macrofossil data from Bolton Fell Moss and Walton Moss, Cumbria, England. Journal of Quaternary Science 13, 515-528.

Barber, K.E., Chambers, F.M., Maddy, D., 2003. Holocene palaeoclimates from peat stratigraphy: macrofossil proxy climate records from three oceanic raised bogs in England and Ireland. Quaternary Science Reviews 22, 521-539. 
Barber, K.E., Chambers, F.M., Maddy, D., Stoneman, R., Brew, J.S., 1994. A sensitive high-resolution record of late Holocene climatic change from a raised bog in northern England. The Holocene 4, 198205.

Blundell, A., 2002: Late Holocene multi-proxy climate records for northern Britain and Ireland derived from raised peat stratigraphy. Unpublished Ph.D. thesis, University of Southampton.

Blundell, A., Charman, D.J., Barber, K., 2008. Multiproxy late Holocene peat records from Ireland: towards a regional palaeoclimate curve. Journal of Quaternary Science 23, 59-71.

Bragg, O.M., Tallis, J.H., 2001.The sensitivity of peat-covered upland landscapes. Catena 42, 345-360.

Blaauw, M., Mauquoy, D., 2012. Signal and variability within a Holocene peat bog - chronological uncertainties of pollen, macrofossil and fungal proxies. Review of Palaeobotany and Palynology 186, $5-15$.

Charman, D.J., Blundell, A., ACCROTELM Members, 2007. A new European testate amoebae transfer function for palaeohydrological reconstruction on ombrotrophic peatlands. Journal of Quaternary Science 22, 209-221.

Charman, D.J., Hendon, D. \& Woodland, W.A., 2000. The Identification of Testate Amoebae (Protozoa: Rhizopoda) in Peats. Technical Guide No. 9, Quaternary Research Association, London, $147 \mathrm{pp}$. 
Daniels, R.E., Eddy, A., 1990. Handbook of European Sphagna. HMSO, London.

De Vleeschouwer, F., Chambers, F.M., Swindles, G.T., 2010. Coring and sub-sampling of peatlands for palaeoenvironmental research. Mires and Peat 7, 1-10.

Ellenberg H., Weber H.E., Dull R., Wirth V., Werner W., Paulisen D. Zeigerwerte von Pflanzen in Mitteleuropa [Indicator values of plants in Central Europe]. 1991. Scripta Geobotanics 18, 1-248.

Farmer, A.M., 1993. The effects of dust on vegetation - a review. Environmental Pollution 79, 63-75.

Flatberg, I., 1986. Taxonomy, morphovariation, distribution and ecology of the Sphagnum imbricatum complex with main reference to Norway. Gunneria 54, 1-118.

Fowler, D., Smith, R.I., Muller, J.B.A., Hayman, G., Vincent, K.J., 2005. Changes in the atmospheric deposition of acidifying compounds in the UK between 1986 and 2001. Environmental Pollution 137, $15-25$

Green, B.H., 1968. Factors influencing the spatial and temporal distribution of S. imbricatum Hornsch Ex. Russ. in the British Isles. Journal of Ecology 56, 47-58.

Grosse-Brauckmann, G., 1972. Über pflanzliche Makrofossilien mitteleuropäischer Torfe. I. Gewebereste krautiger Pflanzen und ihre Merkmale (On plant macrofossils in central European peat. I. Remnants of vascular plant tissues and their characteristics). Telma 2, 19-55 (in German). 
Grosse-Brauckmann, G., 1974. Über pflanzliche Makrofossilien mitteleuropäischer Torfe. II. Weitere Reste (Früchte und Samen, Moose u.a.) und ihre Bestimmungsmöglichkeiten (On plant macrofossils in central European peat. II. Other remnants (e.g. fruits and seeds, mosses) and possibilities for their identification). Telma 4, 51-117 (in German).

Grosse-Brauckmann, G., 1992. Über pflanzliche Makrofossilien mitteleuropäischer Torfe. III. Früchte, Samen und einige Gewebe (Fotos von fossilen Pflanzenresten) (On plant macrofossils in central European peat. III. Fruits, seeds and some tissues (photos of fossil plant remains)). Telma 22, 53-102 (in German).

Gunnarson, U., 2005. Global patterns of Sphagnum productivity. Journal of Bryology 27, 267-277.

Hall, V.A., Mauquoy, D., 2005. Tephra-dated climate and human impact studies during the last 1500 years from a raised bog in central Ireland. The Holocene 15, 1086-1093.

Hall, V.A., Pilcher, J.R., McCormac, F.G., 1993. Tephra-Dated Lowland Landscape History of the North of Ireland, A.D. 750-1150. New Phytologist 125, 193-201.

Hendon, D., Charman, D.J., 1997. The preparation of testate amoebae (Protozoa: Rhizopoda) samples from peat. The Holocene 7, 199-205.

Hill, M.O., Mountford, J.O., Roy, D.B., Bunce, R.G.H. 1999. Ellenberg's indicator values for British plants. Ecofact volume 2 technical annex. Institute of Terrestrial Ecology, Huntingdon. 
Hill, M.O., Preston, C.D., Bosanquet, S.D.S., Roy, D.B., 2007. BRYOATT - Attributes of British and Irish mosses, liverworts and hornworts with information on native status, size, life form, life history, geography and habitat. Centre for Ecology and Hydrology, Huntingdon, 88pp.

Holden, J., Shotbolt, L., Bonn, A., Burt, T.P., Chapman, P.J., Dougill, A.J., Fraser, E.D.G., Hubacek, K., Irvine, B., Kirkby, M.J., Reed, M.S., Prell, C., Stagl, S., Stringer, L.C., Turner, A., Worrall, F., 2007. Environmental change in moorland landscapes. Earth-Science Reviews 82, 75-100.

Hughes, P.D.M., Dumayne-Peaty, L., 2002. Testing Theories of Mire Development Using Multiple Successions at Crymlyn Bog, West Glamorgan, South Wales, UK. Journal of Ecology 90, 456-471.

Hughes, P.D.M., Lomas-Clarke, S.H., Schulz, J., Barber, K.E., 2008. Decline and localized extinction of a major raised bog species across the British Isles: evidence for associated land-use intensification. The Holocene 18, 1033-1043.

Hughes, P.D.M., Lomas-Clarke, S.H., Schulz, J., Jones, P., 2007. The declining quality of late-Holocene ombrotrophic communities and the loss of Sphagnum austinii (Sull. ex Aust.) on raised bogs in Wales. The Holocene 17, 613-625.

Hughes, P.D.M., Mauquoy, D., Barber, K.E., Langdon, P.G., 2000. Mire-development pathways and palaeoclimatic records from a full Holocene peat archive at Walton Moss, Cumbria, England. The Holocene 10, 465-479. 
Hughes, P.D.M., Morriss, S.H., Schulz, J. ,Barber, K.E., 2001. Mire development and human impact in the Teifi Valley: evidence from Tregaron (Cors Caron) peatlands. Quaternary of West Wales Field Guide. Quaternary Research Association, 76-92.

Hughes, P.D.M., Schulz, J., 2001. The development of the Borth Bog (Cors Fochno) mire system and the submerged forst beds at Ynyslas. In Walker, M.J.C. and McCarroll, D., editors, The Quaternary of West Wales field guide. Quaternary Research Association, 104-112.

Hughes, P.D.M, Mallon, G., Brown, A., Essex, H. J., Stanford, J. D., Hotes, S., 2013. The impact of high tephra loading on late-Holocene carbon accumulation and vegetation succession in peatland communities. Quaternary Science Reviews 67, 160-175.

Ireland, A.W., Booth, R.K., 2012. Upland deforestation triggered an ecosystem state-shift in a kettle peatland. Journal of Ecology 100, 586-596.

Jowsey, P.C., 1966. An improved peat sampler. New Phytologist 65, 245-248.

Katz, N.J., Katz, S.V., Skobeyeva, E.I., 1977. Atlas Rastitel'nyh Oostatkov v Torfje (Atlas of Plant Remains in Peats). Nedra, Moscow, 736 pp. (in Russian).

Langdon, P.G., Barber, K.E., 2005. The climate of Scotland over the last 5000 years inferred from multiproxy peatland records: inter-site correlations and regional variability. Journal of Quaternary Science 20, 549-566. 
Lee, J.A., Parsons, A.N., Baxter, R., 1993. Sphagnum species and polluted environments, past and future. Advances in Bryology 5, 297-313.

Mauquoy, D., Barber, K., 1999. Evidence for climatic deteriorations associated with the decline of Sphagnum imbricatum Hornsch. ex Russ. in six ombrotrophic mires from northern England and the Scottish Borders. The Holocene 9, 423-437.

Mauquoy, D., Yeloff, D., Van Geel, B., Charman, D.J., Blundell, A., 2008. Two decadally resolved records from north-west European peat bogs show rapid climate changes associated with solar variability during the mid-late Holocene. Journal of Quaternary Science 23, 745-763.

McClymont, E.L., Mauquoy, D., Yeloff, D., Broekens, P., van Geel, B., Charman, D.J., Pancost, R.D., Chambers, F.M., Evershed, R.P., 2008. The disappearance of Sphagnum imbricatum from Butterburn Flow, UK. The Holocene 18, 991-1002.

Pilcher, J.R., Hall, V.A., McCormac, F.G., 1995. Dates of Holocene Icelandic eruptions from tephra layers in Irish peats. The Holocene 5, 103-110.

Plunkett, G.M., Pilcher, J.R., McCormac, F.G., Hall, V.A. 2004. New dates for first millennium BC tephra isochrones in Ireland. The Holocene 14, 780-786.

Rea H.A., 2011. Peatland records of recent (last c. 250 years) climate change in the North of Ireland. PhD thesis, Queens University Belfast. 
Robroek, B.J.M., Limpens, J., Breeuwer, A., Crushell, P.H., Schouten, M.G.C., 2007. Interspecific competition between Sphagnum mosses at different water tables. Functional Ecology 21, 805-812.

Robroek, B.J.M., Waucomont, J.G.M., Schouten, M.G.C., 2009. The disappearance of S. imbricatum from European raised bogs: a comment on McClymont et al. Holocene 19, 1093-1094.

Roos-Barraclough, F., van der Knaap, W.O., van Leeuwen, J.F.N., Shotyk, W., 2004. A Late-glacial and Holocene record of climatic change from a Swiss peat humification profile. The Holocene 14, 7-19.

Schulte, E.E., Hopkins, B.G., 1996. Estimation of soil organic matter by weight-loss-on-ignition. In F.R. Magdoff et al. (eds.) Soil organic matter: analysis and interpretation. SSSA Spec. Publ. 46, Madison, WI.

Schulz, J., 2004. Late Holocene mire development of the lowland raised bogs Cors Caron and Cors Fochno: a palaeoecological approach using high reoslution macrofossil analysis. Unpublished PhD thesis, University of Southampton.

Smith, A.J.E., 2004. The Moss Flora of Britain and Ireland, Second Edition ed. Cambridge University Press, Cambridge. 
Stoneman, R., Barber, K.E., Maddy, D., 1993 Present and past ecology of Sphagnum imbricatum and its significance in raised peat- climate modelling. Quaternary Newsletter 70, 14-22.

Suyama, Y., Gunnarsson, U., Parducci, L., 2008. Analysis of short DNA fragments from Holocene peatmoss samples. The Holocene 18, 1003-1006.

Swindles, G.T., 2006. Reconstruction of Holocene climate change from peatlands in the north of Ireland, School of Geography, Archaeology and Palaeoecology. Queen's University Belfast, Belfast.

Swindles, G.T., Blundell, A., Roe, H.M., Hall, V.A., 2010a. A 4500-year proxy climate record from peatlands in the North of Ireland: the identification of widespread summer 'drought phases'? Quaternary Science Reviews 29, 1577-1589.

Swindles, G.T., Charman, D.J., Roe, H.M., Sansum, P., 2009. Environmental controls on peatland testate amoebae (Protozoa: Rhizopoda) in the North of Ireland: Implications for Holocene palaeoclimate studies. Journal of Paleolimnology 42, 123-140.

Swindles, G.T., De Vleeschouwer, F., Plunkett, G., 2010b. Dating peat profiles using tephra: stratigraphy, geochemistry and chronology. Mires and Peat 7, 1-9.

Swindles, G.T., Lawson, I.T., Matthews, I.P., Blaauw, M., Daley, T.J., Charman, D.J., Roland, T.P., Plunkett, G., Schettler, G., Gearey, B.R., Turner, T.E., Rea, H.A., Roe, H.M., Amesbury, M.J., Chambers, F.M., Holmes, J., Mitchell, F.J.G., Blackford, J., Blundell, A., Branch, N., Holmes, J., 
Langdon, P., McCarroll, J., McDermott, F., Oksanen, P.O., Pritchard, O., Stastney, O., Stefanini, B., Young, D., Wheeler, J., Becker, K., Armit, I., 2013. Centennial-scale climate change in Ireland during the Holocene. Earth Science Reviews 126, 300-320.

Swindles, G.T., Plunkett, G., Roe, H.M., 2007. A delayed climatic response to solar forcing at 2800 cal. BP: multi-proxy evidence from three Irish peatlands. The Holocene 17, 177-182.

Swindles, G.T., Patterson, R.T., Roe, H.M., Galloway, J.M., 2012. Evaluating periodicities in peatbased climate proxy records. Quaternary Science Reviews 41, 94-103.

Szövényi, P., Hock, Z., Urmi, E., Schneller, J.J., 2006. Contrasting phylogeographic patterns in Sphagnum fimbriatum and Sphagnum squarrosum (Bryophyta, Sphagnopsida) in Europe. New Phytologist 172, 784-794.

Thingsgaard, K., 2002. Taxon delimitation and genetic similarities of the Sphagnum imbricatum complex, as revealed by enzyme electrophoresis. Journal of Bryology 24, 3-15.

Turner, T.E., Swindles, G.T. and Roucoux, K.H. (2014) Late Holocene ecohydrological and carbon dynamics of a UK raised bog: impact of human activity and climate change. Quaternary Science Reviews 84, 65-85. 
Väliranta, M. Blundell, A., Charman, D.J., Karofeld, E., Korhola, A., Sillasoo, Ü., Tuittila, E.-S., 2012. Reconstructing peatland water tables using transfer functions for plant macrofossils and testate amoebae: A methodological comparison, Quaternary International 268, 34-43.

van Geel, B., Middeldorp, A.A., 1988. Vegetational history of Carbury Bog (Co. Kildare, Ireland) during the last 850 years and a test of the temperature indicator value of $2 \mathrm{H} / 1 \mathrm{H}$ measurements of peat samples in relation to historical sources and meteorological data. New Phytologist 109, 377392. 


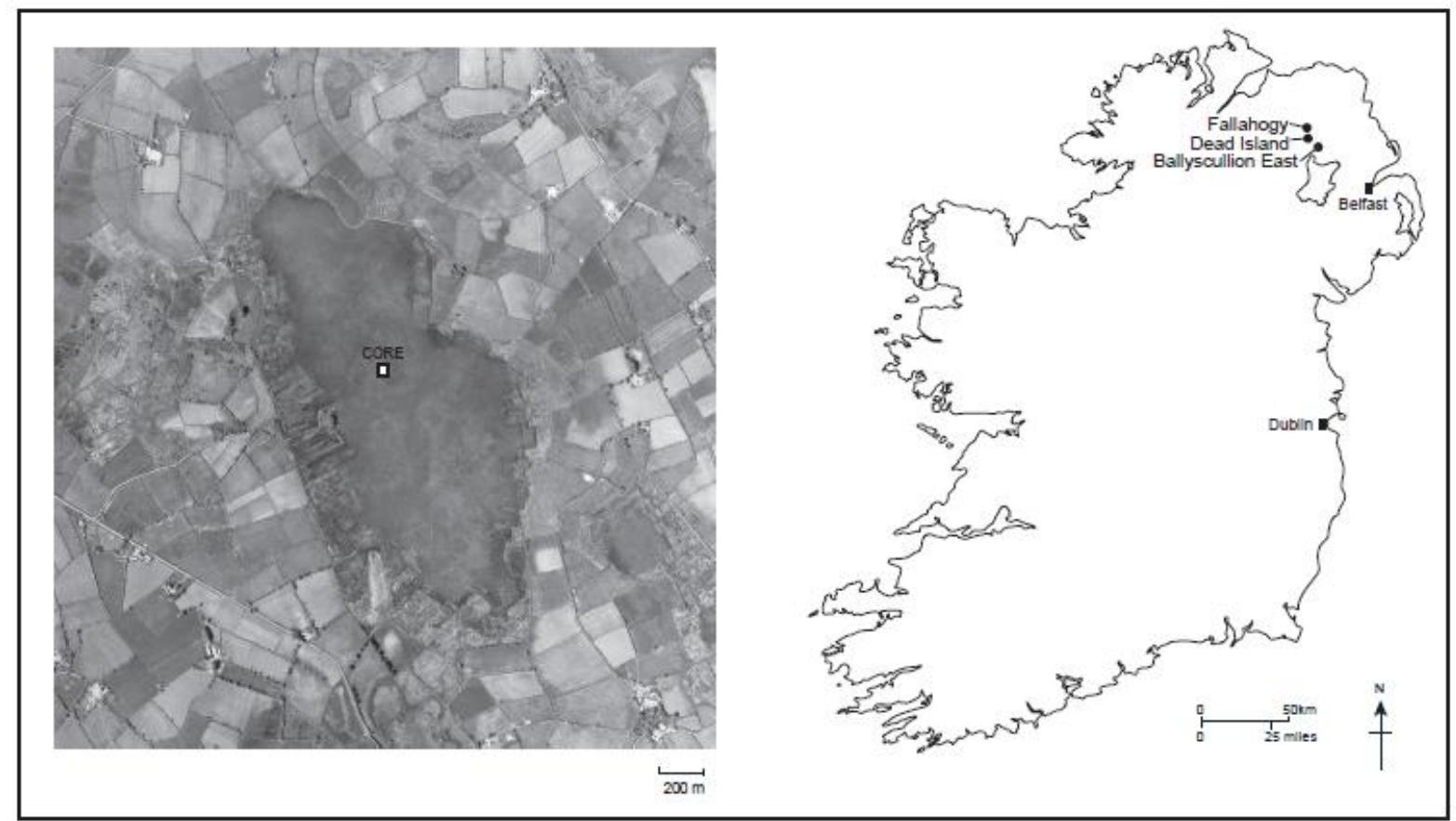

Figure 1 


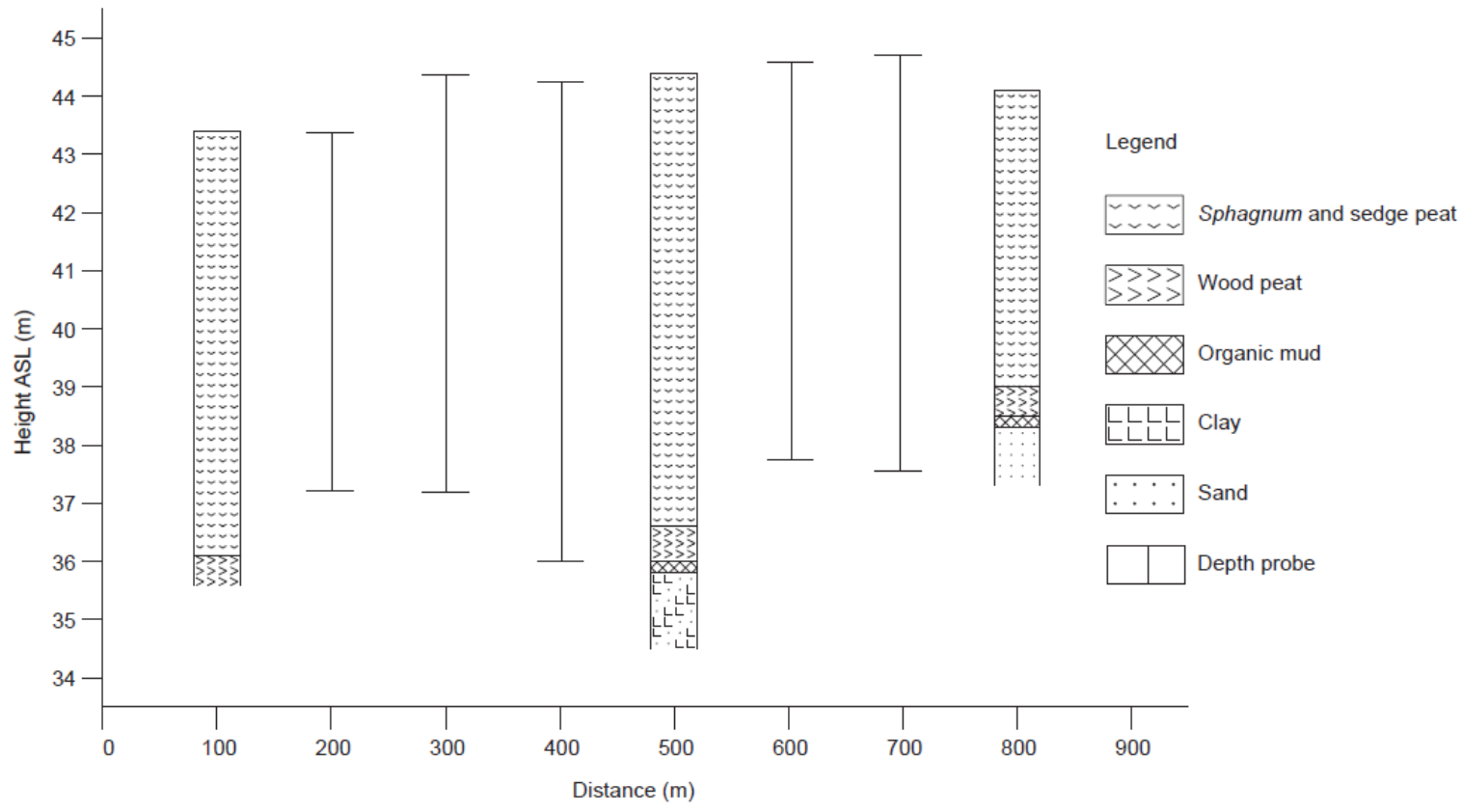

Figure 2 


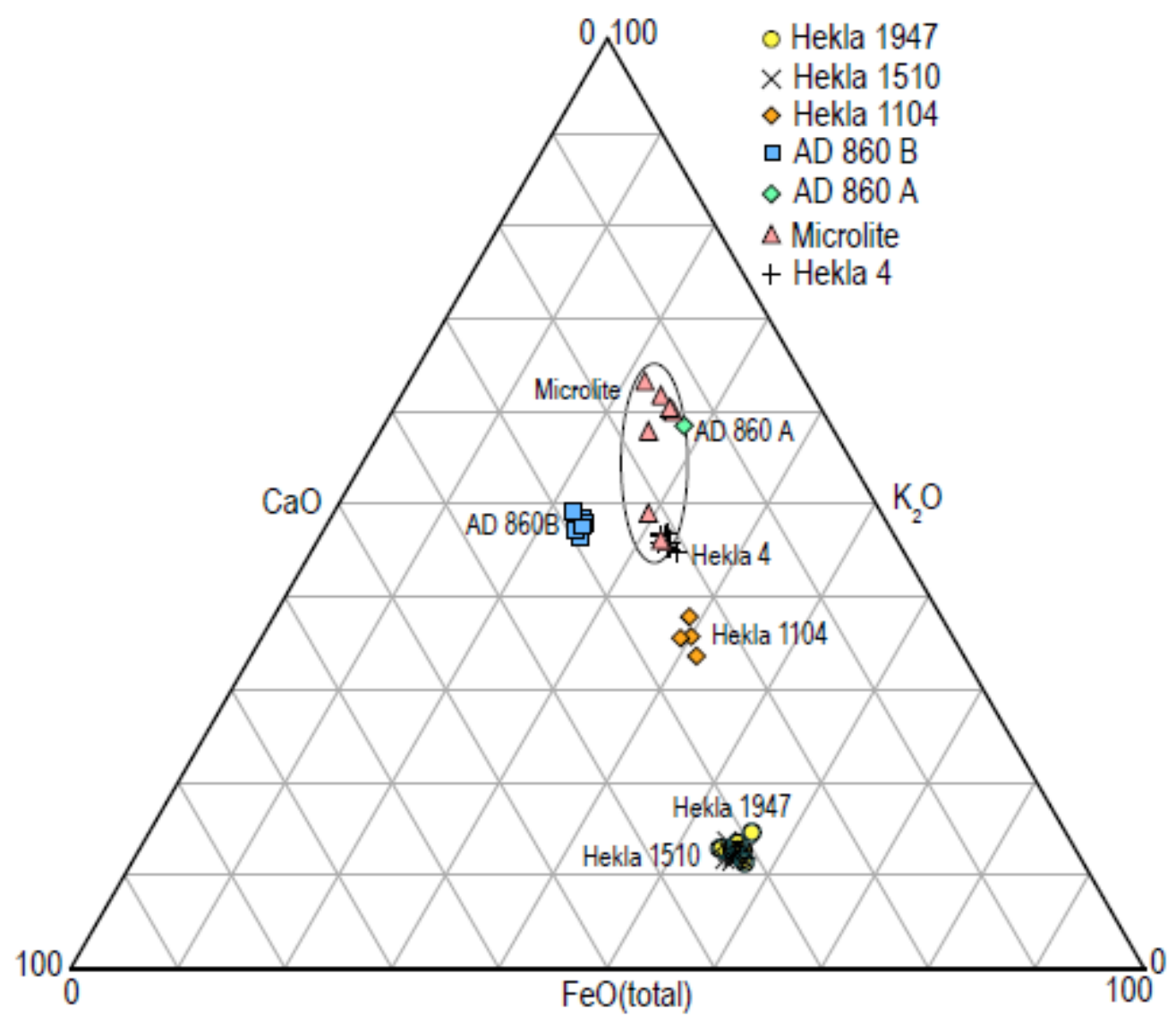

Figure 3 


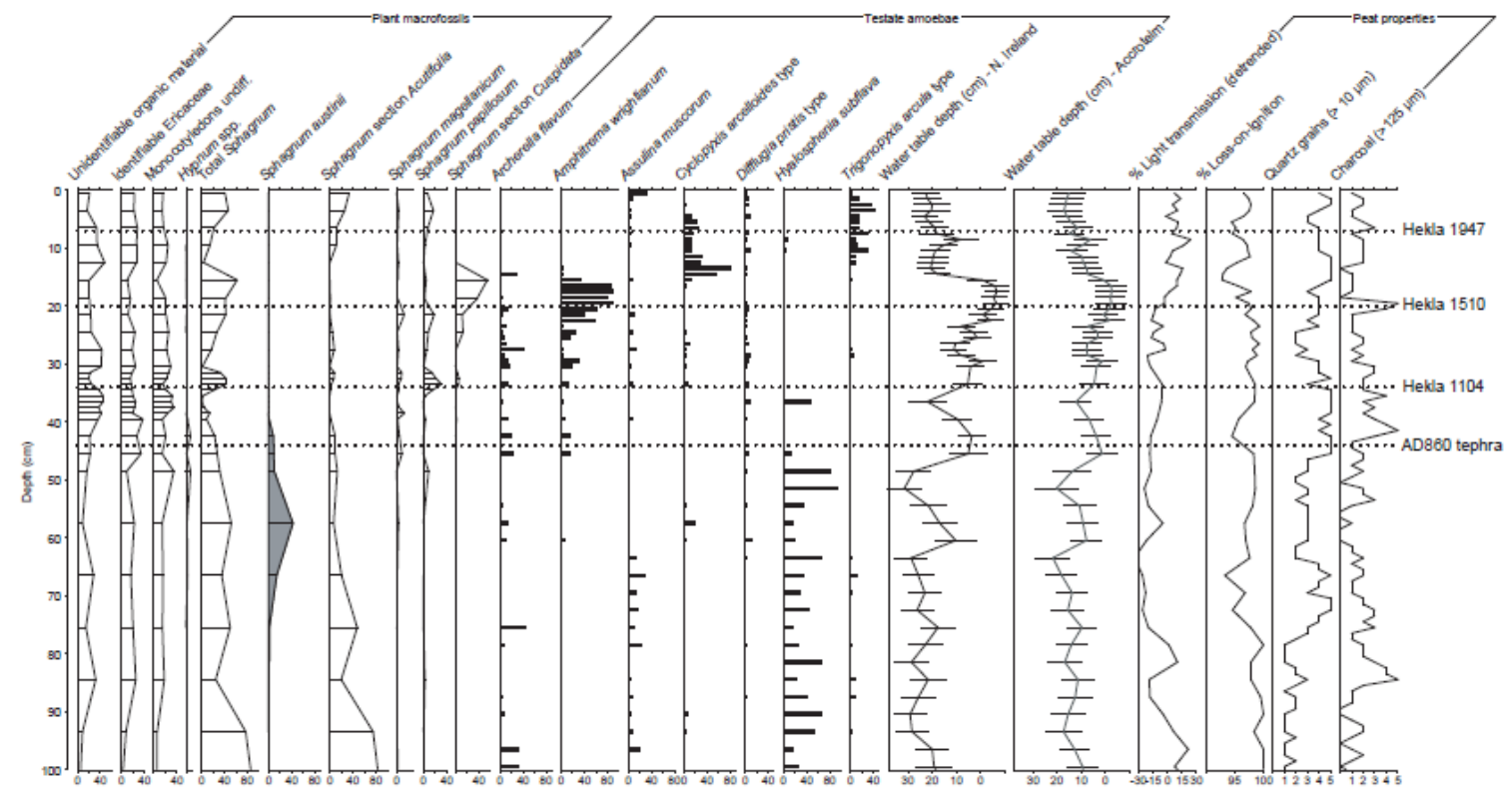

Figure 4 


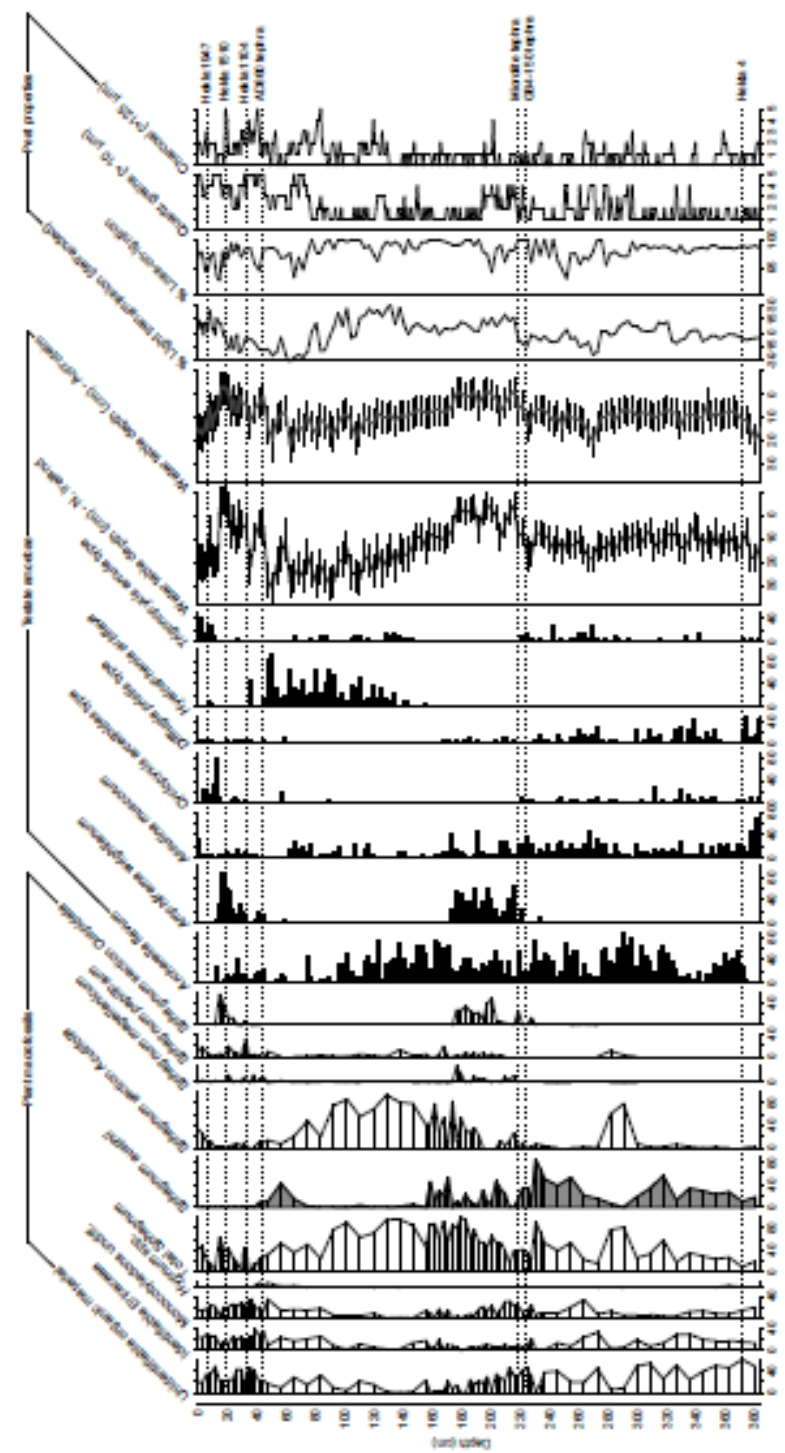

Figure 5 


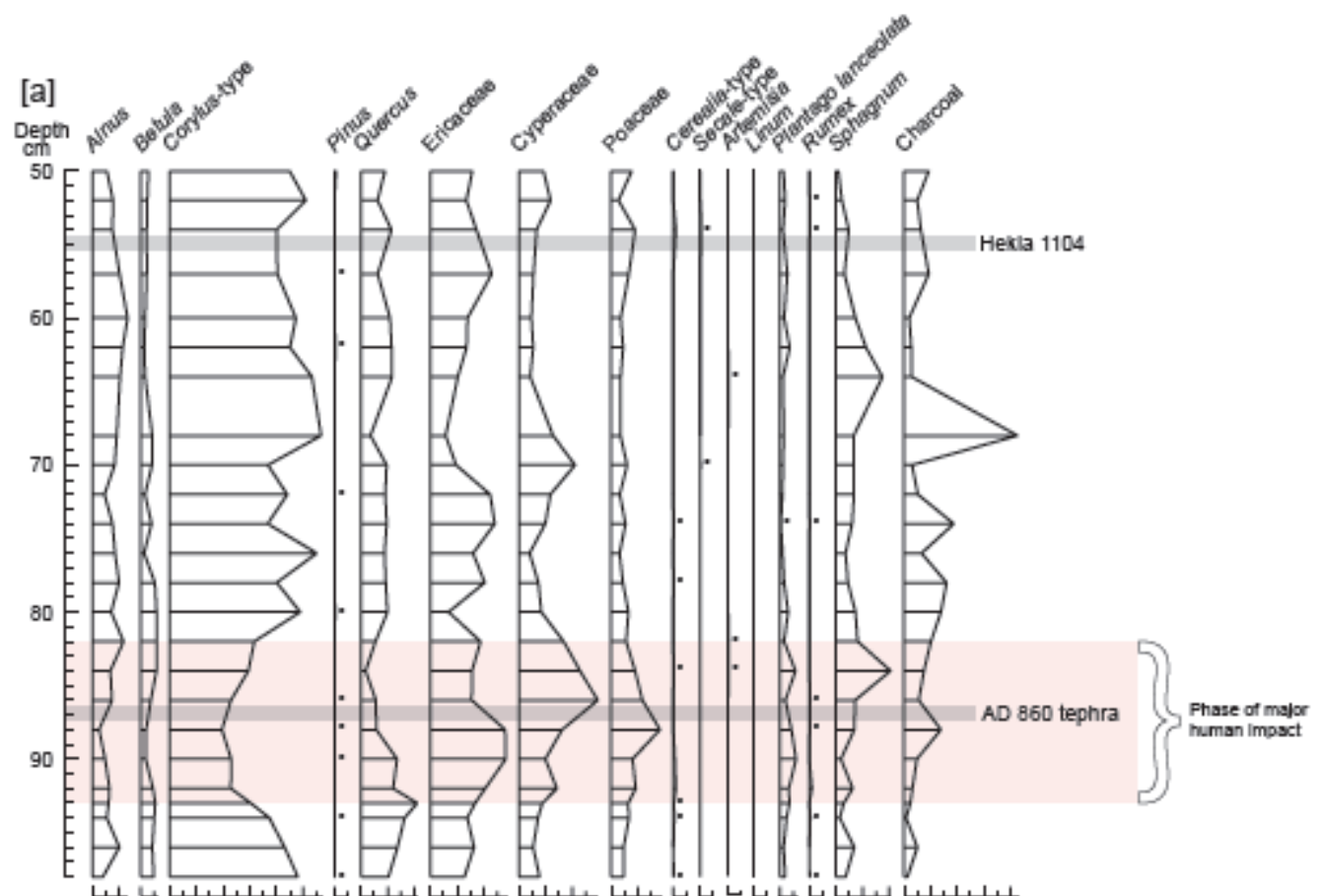

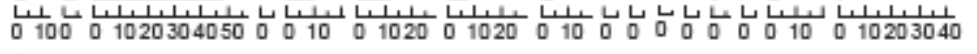
$\%$

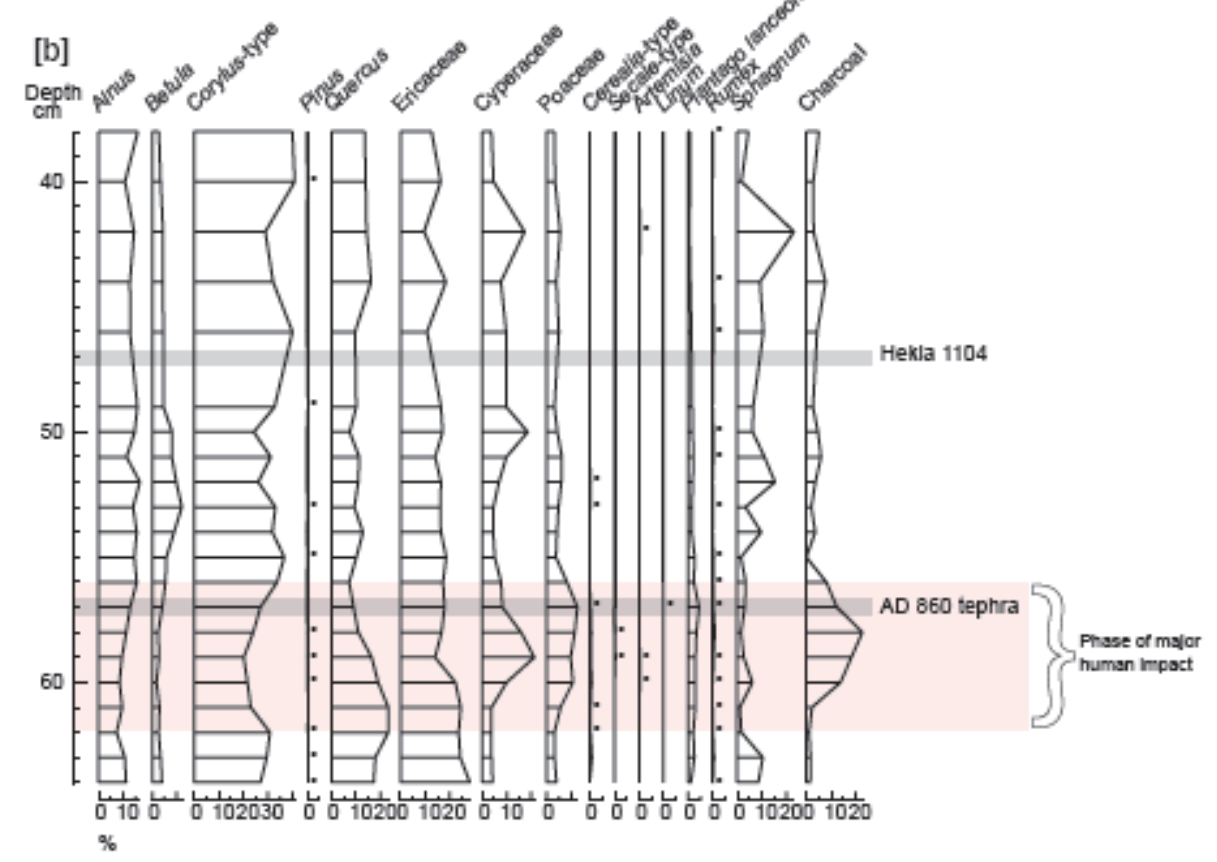

Figure 6 

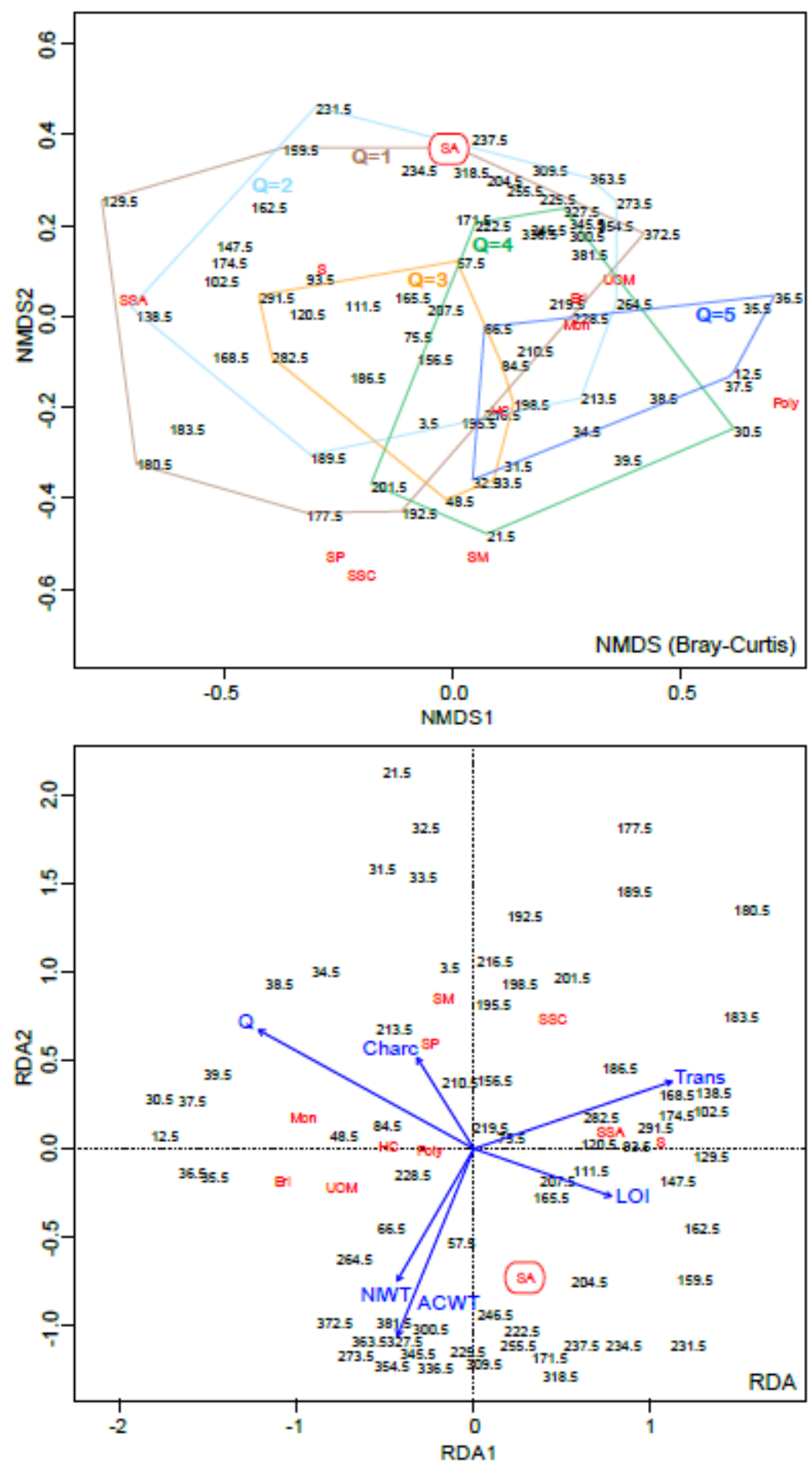

Figure 7 


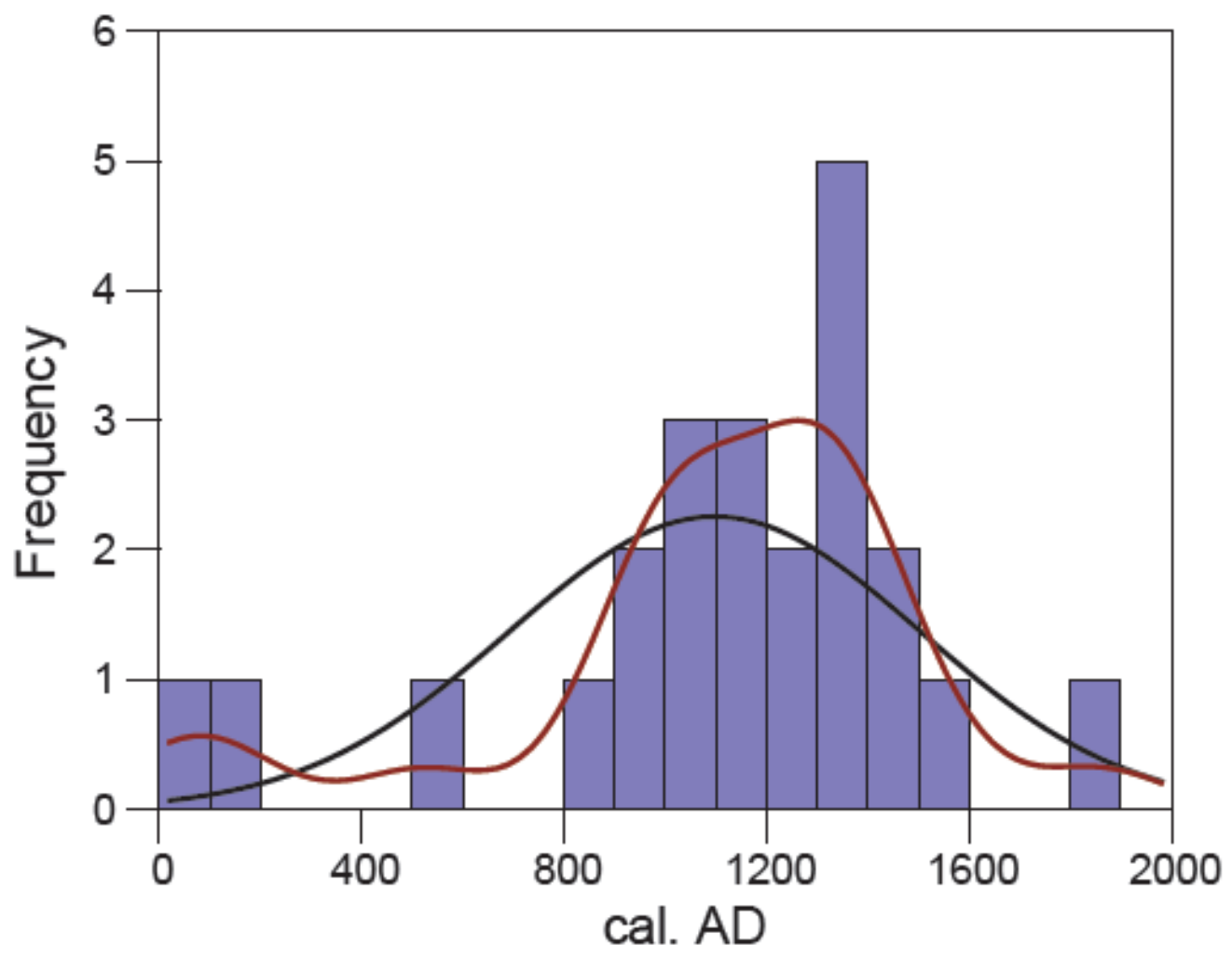

Figure 8 
Table 1

\begin{tabular}{|l|r|l|l|}
\hline Variables & \multicolumn{1}{l|}{ rs } & $\mathrm{p}<0.05(\mathrm{n}=76)$ & $\mathrm{p}<0.01 \quad(\mathrm{n}=76)$ \\
\hline Charcoal & -0.36 & & $\checkmark$ \\
\hline Transmission & -0.09 & & \\
\hline LOI & 0.29 & $\checkmark$ & \\
\hline NI WT & -0.01 & & \\
\hline AC WT & 0.03 & & \\
\hline Q & -0.47 & & $\checkmark$ \\
\hline
\end{tabular}


Table 2

\begin{tabular}{|c|c|c|}
\hline Site & Location & Date of decline c. AD \\
\hline Dead Island & N. Ireland & 980 This study \\
\hline Fallahogy & N. Ireland & 1860 Rea (2011) \\
\hline Abbeyknockmoy & Ireland & 1000 Hughes et al. (2008) \\
\hline Ardkill & Ireland & 1250 Blundell et al. (2007) \\
\hline Mongan & Ireland & 1350 Hall and Mauquoy (2005) \\
\hline Carbury & Ireland & 1400 van Geel and Middeldorp (1988) \\
\hline Crymlyn & Wales & 875 Hughes and Dumayne-Peaty (2002) \\
\hline Cors Caron & Wales & 1540 Hughes et al. (2001) \\
\hline Cors Fochno & Wales & 1100 Hughes and Schulz (2001) \\
\hline Rhos Goch Common & Wales & 1040 Hughes et al. (2007) \\
\hline Butterburn Flow & England & 1300 McClymont et al. (2008) \\
\hline Heathwaite & England & 520 Blundell (2002) \\
\hline Walton & England & 1340 Hughes et al. (2000) \\
\hline Bolton Fell & England & 1130 Mauquoy and Barber (1999) \\
\hline Malham Tarn & England & 26 Turner et al. (2014) \\
\hline Raeburn Flow & Scotland & 1335 Mauquoy and Barber (1999) \\
\hline Bell's Flow & Scotland & 1225 Mauquoy and Barber (1999) \\
\hline Coom Rigg & Scotland & 1440 Mauquoy and Barber (1999) \\
\hline Longbridge & Scotland & 1135 Langdon and Barber (2005) \\
\hline Langlands & Scotland & 960 Langdon and Barber (2005) \\
\hline Temple Hill & Scotland & 135 Langdon and Barber (2005) \\
\hline Shirgarton & Scotland & 1305 Langdon and Barber (2005) \\
\hline Tore Hill & Scotland & 1000 Blundell and Barber (2005) \\
\hline
\end{tabular}




\section{Highlights}

- We examine the cause of the Sphagnum austinii decline in a raised bog.

- The decline occurs at a time of increased soil-derived dust and increased charcoal.

- Pollen records reveal that the decline occurred during a period of agricultural intensification. 